\title{
Early experiences of abuse and current depressive disorders in Iranian women
}

Gh.R. Ghassemi, ${ }^{\text {S. Sadeghi, }}{ }^{2}$ Gh.A. Asadollahi, ${ }^{\text {A. }}$ R. Yousefy ${ }^{3}$ and S. Mallik ${ }^{4}$

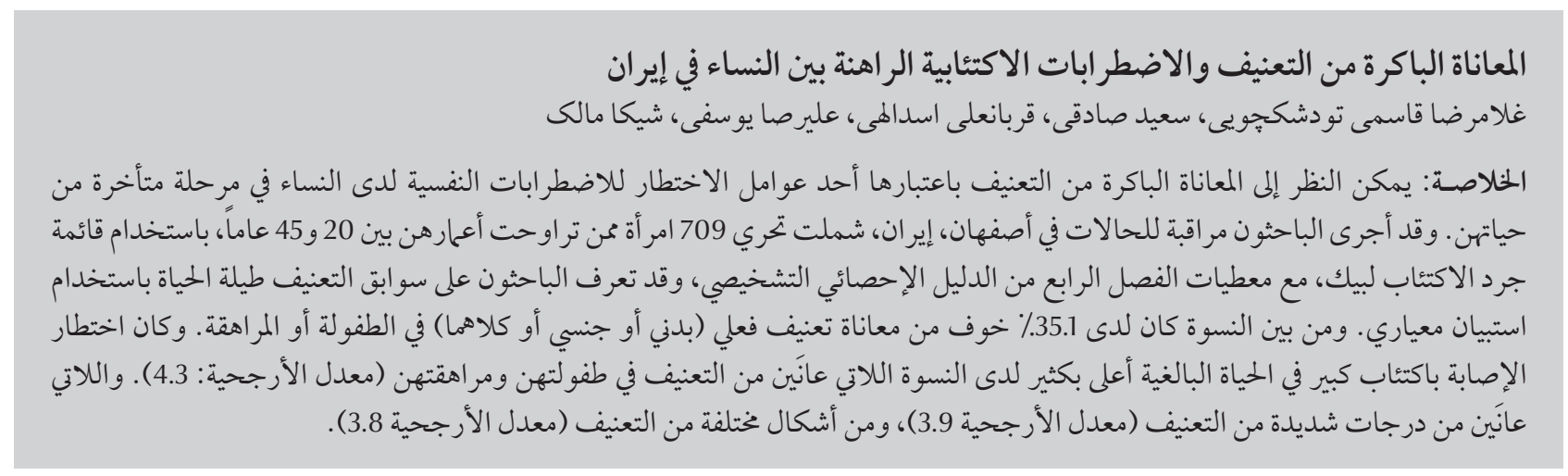

ABSTRACT Early experience of abuse may be viewed as a risk factor for mental disorders in women later in life. This case-control study in Isfahan screened 709 women aged 20-45 years using the Beck Depression Inventory and structured clinical interviews for Diagnostic Statistical Manual-IV criteria. Lifetime history of abuse was determined using a standard questionnaire. Among the women $35.1 \%$ had experienced fear of or actual abuse (physical, sexual or both) in childhood or adolescence. The risk of having major depression in adult life was significantly higher in women who experienced abuse in childhood and adolescence (OR 4.3), severe degrees of abuse (OR 3.9) or multiple forms of abuse (OR 3.8).

\section{Expériences précoces de maltraitance et troubles dépressifs chez les femmes iraniennes}

RÉSUMÉ Les expériences précoces de maltraitance peuvent être considérées comme un facteur de risque de développement des troubles mentaux chez la femme à l'âge adulte. Au cours de cette étude de cas-témoins réalisée à Ispahan, 709 femmes âgées de 20 à 45 ans ont été examinées à l'aide de l'inventaire de dépression de Beck et d'entretiens cliniques structurés fondés sur les critères du DSM IV (4 ème édition du manuel diagnostique et statistique des troubles mentaux). Les antécédents de maltraitance ont été décelés à l'aide d'un questionnaire standard. Parmi les femmes du groupe étudié, 35,1 \% d'entre elles ont souffert de craintes de maltraitance ou de maltraitance réelle (physique, sexuelle ou les deux) au cours de l'enfance ou de l'adolescence. Le risque de dépression majeure à l'âge adulte était nettement plus élevé chez les femmes ayant subi des maltraitances au cours de l'enfance ou de l'adolescence (odd ratio = 4,3), de forts niveaux de maltraitance (odd ratio $=3,9$ ) ou de multiples formes de maltraitance (odd ratio $=3,8$ ). 


\section{Introduction}

Gender-based violence occurs throughout the world, irrespective of culture, ethnicity and socioeconomic status [1-9]. Its health consequences can be as severe as disability or death but its social and psychological complications are less easy to measure. In 1993, in the Declaration of the Elimination of Violence against Women, the United $\mathrm{Na}$ tions defined violence against women to include physical, sexual and psychological harm [1]. In Asian countries, violence against women is widespread [4-7]. In Egypt, Palestine, Israel and Tunisia one-third of women have been a victim of physical abuse [8]. In a recent study of 650 Iranian women, a quarter of them had experienced some kind of spouse abuse; $67.8 \%$ were victims of psychological abuse, $58.8 \%$ sexual violence and $39.4 \%$ physical violence [9]. The high rate of violence against women in our and other Islamic nations is a reflection of cultural values rather than religious identity [8]. In fact, domestic violence is strongly prohibited in the Holy Quran (101:1).

The experience of abuse is considered one of the risk factors for mental disorders in women [10-16]. Child sexual abuse is associated with longterm problems such as fear, anxiety, substance abuse, suicidal ideation, low self-esteem, a tendency towards victimization, increased insomnia, hypervigilance, augmented startle response and a sense of disorder and unhappiness. The high prevalence of both psychiatric disorders and gender-basedviolencesuffered by women suggests a relationship between them which needs empirical study.

There is a dearth of literature about the magnitude and psychological complications of gender-based violence in the Islamic Republic of Iran. This community-based study of women was specifically designed to measure the prevalence of exposure to abuse as a child or adolescent, and to examine the association of such exposure with major depression in adulthood.

\section{Methods}

\section{Sample}

Considering the sensitive nature of the problem, this study was conducted as part of a series of lectures on family mental health, conducted in a community mental health centre, to which women were invited to attend. The women were generally accompanied by their mothers or elder siblings and agreed to participate voluntarily after reassurances were given about the confidentiality of the data.

Using clustered multi-stage random sampling, we selected the minimum sample of 976 from the 100 clusters across 4 geographical zones (north, south, east and west) of Isfahan, Islamic Republic of Iran. We randomly assigned 20 households from every zone which functioned as clusters, generating a database with 2350 household members. Women belonging to households that fell into the sampling list in each zone were invited to attend the lectures. From March 2003 to August 2004, at least 1855 women registered for the programme but only 1332 of them attended the first lecture and only 922 were willing to participate in the study.

Only women aged between 20 and 45 years were included, to exclude the confounding role of physical/mental immaturity or hormonal/menopausal changes. To be able to complete the self-administered questionnaires, the women had to have at least primary education. Women who did not provide written consent and who had clear signs of physical and mental disability were excluded from the list.

\section{Assessing past and current depression}

Participants were initially screened for current depression with a Farsi version of the Beck Depression Inventory
(BDI) $[17,18]$. This was pilot-tested on 80 adults, yielding a Cronbach value of 0.89 . A history of past depression was assessed in the women with 4 questions: (1) whether there had ever been a time when she was feeling depressed or "down" most of the day, nearly every day and for at least 2 weeks; (2) whether she had been diagnosed with depression by a health professional; (3) whether she had sought treatment for depression; and (4) whether she had ever used antidepressant drugs for 6 months or longer.

All women with high scores on the BDI ( $\geq 11)$ or who reported a past history of depression (418 cases) were assessed for clinical depression by faceto-face structured clinical interviews using Diagnostic Statistical Manual-IV criteria by 2 senior psychiatrists who were blind to the study [19]. Of these, 309 women were diagnosed with major depression and 143 of them agreed to continue with the study. Women with low scores $(<11)$ on the BDI, and who answered no to all questions about a history of depression were entered in the nondepressed group. The final analysis of data was therefore based on 709 women: 143 depressed (clinical cases) and 566 nondepressed (controls).

\section{Assessing experience of violence}

The women's experiences of violence across their lifespan was assessed by means of a self-developed questionnaire which was adopted from the conflict tactics scale and the pregnancy abuse assessment screen $[20,21]$. The English versions of the scales were initially translated into Farsi by a group of bilingual experts who were ignorant about their themes. To test the language validity, the Farsi version was back-translated into English by another group of bilingual experts. This self-administered questionnaire allowed us to include whether the woman had witnessed violence or threats of violence and her life stage at exposure (i.e. childhood, 
adolescence, and adulthood). Finally, the extended and modified forms of the instruments were administered to a sample of 69 female visitors at a social work clinic. The test-retest reliability of the questionnaire was established by Cronbach alpha $=0.81$.

The questionnaire was anonymous and comprised 2 sections: the first one included questions about the participant's demographic characteristics (age, marital status, education and occupational status), as well as self-reported family history of depression (i.e. any family member being under psychiatric treatment for depression). The second section enquired about the stage of abuse (childhood or adolescence or both) and type of abuse (physical or sexual or both). For each stage-specific and abuse-specific question, the participant was asked to select the category that best described the frequency of exposure to the act (never, less than a few times, a few times or more than a few times). For the purpose of analysis, the type of abuse and its frequency were converted to a category called severity of abuse. Two trained social workers administered the questionnaires and clarified the respondents' queries as required.

\section{Definitions}

Violent victimization was defined as any reported experience or fear of physical or sexual abuse. We grouped fear of abuse and experience of abuse together because a majority of the women who reported actual experiences of abuse also reported fear of abuse. For all the analyses, we defined the reference category as a woman who had never experienced or feared abuse in her life, with the exception of being spanked in childhood a few times.

Physical abuse referred to threatened, attempted or actual infliction of physical harm, such as being pushed, grabbed, shoved, kicked, bitten, punched, spanked, choked, burned, hit by an object or individually or physically attacked in any other way; or fear that abuse would be directed towards someone else in their home. Sexual abuse referred to threatened, attempted or actual infliction of sexual harm, such as sexual assault, or someone "being sexual" or exposing his genitals against her will.

Severity of abuse was categorized into 3 levels: mild, moderate and severe. These categories were extensions of the criteria of severity in the Conflict Tactics Scale and the Pregnancy Abuse Assessment Screen and were based on the expert opinions of a family sociologist and a psychiatrist with good experience in crisis intervention and domestic violence. Mild abuse was defined as experience or fear of physical abuse (a few times or less); or witnessing other people experiencing any type of abuse (a few times or less); or being spanked (more than a few times). Moderate abuse was defined as experience or fear of physical abuse (more than a few times); or sexual exposure (a few times or less). Severe abuse was defined as experience or fear of physical abuse (more than a few times); or sexual exposure (more than a few times); or sexual assault (ever); or fearing that someone they loved would be killed (ever). Missing answers were assumed to signify no abuse.

\section{Analysis}

The data were analysed using SPSS, version 11. Chi-squared and logistic regression analyses were done to calculate odds ratios (OR) and $95 \%$ confidence intervals (CI) and determine the association between violent victimization and depression and to adjust for potential confounders.

Covariates included in the final model were family history ofdepression (no versus yes), age group, education (primary, secondary or undergraduate) and marital status (never married, married or divorced/separated/ widowed).

\section{Results}

Of the 706 women, 143 were diagnosed with major depression (case group) and 566 without depression (control group), a prevalence of depression in this study of $20.2 \%$.

\section{Background characteristics}

A majority of the respondents in the case group were unmarried while more of those in the control group were unmarried. In both groups a majority held clerical positions in a private or government organization. A positive family history of depression was reported by significantly more women in the case group (49.7\%) than in the control group $(24.2 \%)(P<0.001)($ Table 1$)$.

\section{Prevalence of abuse}

Out of 709 women, 250 (35.1\%) reported experience of any kind of victimization at some stage of their life; $150(21.2 \%)$ women had experienced physical abuse, $53(7.5 \%)$ sexual abuse and $47(6.6 \%)$ both physical and sexual abuse. However, more women in the case group $(63,44.1 \%)$ had suffered any kind of abuse compared with the control group (186, 32.9\%), and the difference was statistically significant $(P$ $<0.01)$ (Table 2).

Some of the women $(65,9.2 \%)$ had been victimized in childhood, but more had suffered abuse in adolescence (19.0\%). Significantly more women in the case group had been victimized in both childhood and adolescence than in the control group (15.0\% versus $4.4 \%$ ) $(P<0.001)$ (Table 3$)$. The same was true for those abused only in childhood $(23.1 \%$ versus $5.7 \%)(P<0.001)$ or only in adolescence $(28.0 \%$ versus $11.3 \%)(P$ $=0.04$ ).

Overall $8.7 \%$ of the women had experienced mild forms of abuse, $16.2 \%$ moderate abuse and $10.3 \%$ severe abuse. A significantly higher proportion of cases had suffered all degrees of abuse than the control group (Table 4); $23.1 \%$ of cases had suffered severe 


\begin{tabular}{|c|c|c|c|c|c|c|}
\hline \multirow[t]{2}{*}{ Demographic characteristic } & \multicolumn{2}{|c|}{ Cases $(n=143)$} & \multicolumn{2}{|c|}{ Controls $(n=566)$} & \multicolumn{2}{|c|}{ Total $(n=709)$} \\
\hline & No. & $\%$ & No. & $\%$ & No. & $\%$ \\
\hline \multicolumn{7}{|l|}{ Age (years) } \\
\hline 20-25 & 24 & 16.8 & 115 & 20.3 & 139 & 19.6 \\
\hline $26-30$ & 37 & 25.9 & 109 & 19.3 & 146 & 20.6 \\
\hline $31-35$ & 25 & 17.5 & 113 & 20.0 & 138 & 19.5 \\
\hline $36-40$ & 20 & 14.0 & 125 & 22.1 & 145 & 20.5 \\
\hline $41-45$ & 37 & 25.9 & 104 & 18.4 & 141 & 19.9 \\
\hline \multicolumn{7}{|l|}{ Marital status } \\
\hline Married & 40 & 28.0 & 252 & 44.5 & 292 & 41.2 \\
\hline Never married & 75 & 52.4 & 197 & 34.8 & 272 & 38.4 \\
\hline Divorced/separated & 28 & 19.6 & 117 & 20.7 & 145 & 20.5 \\
\hline \multicolumn{7}{|l|}{ Educational status } \\
\hline Primary & 41 & 28.7 & 198 & 35.0 & 239 & 33.7 \\
\hline Secondary & 69 & 48.3 & 251 & 44.3 & 320 & 45.1 \\
\hline Undergraduate & 24 & 16.8 & 84 & 14.8 & 108 & 15.2 \\
\hline Graduate & 9 & 6.3 & 33 & 5.8 & 42 & 5.9 \\
\hline \multicolumn{7}{|l|}{ Occupational status } \\
\hline Housewife & 35 & 24.5 & 71 & 12.5 & 106 & 15.0 \\
\hline Student & 15 & 10.5 & 55 & 9.7 & 70 & 9.9 \\
\hline Teacher & 24 & 16.8 & 95 & 16.8 & 119 & 16.8 \\
\hline Clerical worker & 36 & 25.2 & 172 & 30.4 & 208 & 29.3 \\
\hline Self-employed & 18 & 12.6 & 90 & 15.9 & 108 & 15.2 \\
\hline Unemployed & 15 & 10.5 & 83 & 14.7 & 98 & 13.8 \\
\hline \multicolumn{7}{|l|}{ Family history of depression } \\
\hline Yes & 71 & 49.7 & 137 & 24.2 & 208 & 29.3 \\
\hline No & 72 & 50.3 & 429 & 75.8 & 501 & 70.7 \\
\hline
\end{tabular}

abuse compared with $7.1 \%$ of controls $(P<0.001)$.

\section{Risk of major depression}

After adjustment for potential confounders, logistic regression was used to determine the role of stage of abuse, type of abuse and severity of abuse in the risk of suffering major depression. Table 5 shows that stage of abuse (i.e. suffering abuse throughout both childhood and adolescence) was themostimportant risk factor for predicting major depression in adulthood ( $\mathrm{OR}=4.2$; 95\% CI: $1.9-9.3$ ). Severity of abuse was the second most important risk factor $(\mathrm{OR}=3.9 ; 95 \% \mathrm{CI}$ : 3.0-5.1) and the type of abuse (i.e. both sexual and physical abuse) was the third $(\mathrm{OR}=3.8 ; 95 \% \mathrm{CI}: 1.7-8.1)$.

\begin{tabular}{|c|c|c|c|c|c|c|}
\hline \multirow{3}{*}{ Type of abuse } & \multirow{2}{*}{\multicolumn{2}{|c|}{ Cases $(n=143)$}} & \multirow{2}{*}{\multicolumn{2}{|c|}{ Controls $(n=566)$}} & \multirow{2}{*}{\multicolumn{2}{|c|}{ Total $(n=709)$}} \\
\hline & & & & & & \\
\hline & No. & $\%$ & No. & $\%$ & No. & $\%$ \\
\hline \multicolumn{7}{|l|}{ Physical } \\
\hline Yes & 49 & 34.3 & 101 & 17.8 & 150 & 21.2 \\
\hline No & 94 & 65.7 & 465 & 82.2 & 559 & 78.8 \\
\hline & \multicolumn{6}{|c|}{$\chi^{2}=16.9, P<0.001$} \\
\hline \multicolumn{7}{|l|}{ Sexual } \\
\hline Yes & 19 & 13.3 & 34 & 6.0 & 53 & 7.5 \\
\hline No & 124 & 86.7 & 532 & 94.0 & 656 & 92.5 \\
\hline & \multicolumn{6}{|c|}{$\chi^{2}=7.7, P<0.01$} \\
\hline \multicolumn{7}{|c|}{ Physical \& sexual } \\
\hline Yes & 13 & 9.1 & 34 & 6.0 & 47 & 6.6 \\
\hline No & 130 & 90.0 & 532 & 94.0 & 662 & 93.4 \\
\hline \multicolumn{7}{|c|}{$\chi^{2}=1.6, P<0.01$} \\
\hline
\end{tabular}




\begin{tabular}{|c|c|c|c|c|c|c|}
\hline \multirow{2}{*}{$\begin{array}{l}\text { Stage of } \\
\text { abuse }\end{array}$} & \multicolumn{2}{|c|}{ Cases $(n=143)$} & \multicolumn{2}{|c|}{ Controls $(n=566)$} & \multicolumn{2}{|c|}{ Total $(n=709)$} \\
\hline & No. & $\%$ & No. & $\%$ & No. & $\%$ \\
\hline \multicolumn{7}{|c|}{ Childhood } \\
\hline Yes & 33 & 23.1 & 32 & 5.7 & 65 & 9.2 \\
\hline \multirow[t]{2}{*}{ No } & 110 & 76.9 & 534 & 94.3 & 644 & 90.8 \\
\hline & \multicolumn{6}{|c|}{$\chi^{2}=34.1, P<0.001$} \\
\hline \multicolumn{7}{|c|}{ Adolescence } \\
\hline Yes & 40 & 28.0 & 98 & 11.3 & 138 & 19.5 \\
\hline No & 103 & 72.0 & 468 & 82.7 & 571 & 80.5 \\
\hline \multicolumn{7}{|c|}{$\begin{array}{l}\text { Childhood \& } \\
\text { adolescence }\end{array}$} \\
\hline Yes & 22 & 15.0 & 25 & 4.4 & 47 & 6.6 \\
\hline \multirow[t]{2}{*}{ No } & 121 & 84.6 & 541 & 95.6 & 662 & 93.4 \\
\hline & \multicolumn{6}{|c|}{$\chi^{2}=18.3, P<0.001$} \\
\hline
\end{tabular}

\section{Discussion}

Analysis of the data showed that $35.1 \%$ of women in this study had a history of fear of, or actual experience of, physical or sexual abuse in their childhood or adolescence. The rates of abuse ranged from $21.2 \%$ for physical abuse to $7.5 \%$ for sexual abuse and $6.6 \%$ for both physical and sexual abuse. These observations reinforce earlier findings in the Islamic Republic of Iran by Zand [9] and confirm an alarmingly high rate of violence suffered by women in Iranian society. Our findings are similar to those reported in countries such as India, Pakistan, Egypt, Palestine and Tunisia where one-third of women are a victim of physical abuse [5-8]. In a population-based study in Canada by MacMillan et al. $21.1 \%$ of women reported a history of physical abuse as a child [22].

The proportion of women with experience of any kind of abuse was significantly higher in the case group of depressed women (44.1\%) than the control group (32.9\%). Similarly, significantly more cases than controls had suffered abuse in all stages (childhood or adolescence or both), all types (sexual or physical or both) and all degrees of severity (mild, moderate or severe).
The prevalence of major depression in our study was $20.2 \%$. No woman in the control group suffered from major depression. However, $35.1 \%$ of the entire sample (249 out of 709 women) reported being victimized at some stage of their life. For the case group, major depression was more prevalent among women with a history of abuse in childhood and adolescence. These differences were statistically significant. The logistic regression model showed that the risk of major depression was highest for women who had suffered abuse throughout both childhood and adolescence (4.3-fold increased risk), those who had been both physically and sexually abused (3.8-fold increased risk) and those who had suffered severe forms of abuse (3.9-fold increased risk)

Studiespertaining towomen'shealth have consistently pointed to the role of physical and sexual abuse in development of major depression in adulthood. In this respect our findings lend support to the hypothesis that early life victimization can contribute to adult depression. These observations are in line with the findings of researchers in several parts of the world. It has been repeatedly shown that early childhood trauma can lead to an array of negative health outcomes and behaviours [23-26]. Victimized women succumb to a wide range of psychological disturbances including major depression, post-traumatic stress disorder, low self-confidence, anxiety and suicidal behaviour [27-29].

The biological and neurological consequences of violence against women were not dealt with in this study and are a neglected area of research. Some studies have shown diminishing of $\mathrm{T}$ cell functionality following domestic violence [30]. In tragic situations violence and victimization may even result in death. In the Islamic Republic of Iran

\begin{tabular}{|c|c|c|c|c|c|c|}
\hline \multicolumn{7}{|c|}{$\begin{array}{l}\text { Table } 4 \text { Distribution of the women by degree of victimization comparing women } \\
\text { with major depression (cases) and women without major depression (controls) }\end{array}$} \\
\hline \multirow[t]{2}{*}{ Degree of abuse } & \multicolumn{2}{|c|}{ Cases $(n=143)$} & \multicolumn{2}{|c|}{ Controls $(n=566)$} & \multicolumn{2}{|c|}{ Total $(n=709)$} \\
\hline & No. & $\%$ & No. & $\%$ & No. & $\%$ \\
\hline \multicolumn{7}{|l|}{ Mild } \\
\hline Yes & 22 & 15.4 & 40 & 7.1 & 62 & 8.7 \\
\hline \multirow[t]{2}{*}{ No } & 121 & 84.6 & 526 & 92.9 & 647 & 91.3 \\
\hline & \multicolumn{6}{|c|}{$\chi^{2}=9.9, P<0.001$} \\
\hline \multicolumn{7}{|l|}{ Moderate } \\
\hline Yes & 33 & 23.1 & 82 & 14.5 & 115 & 16.2 \\
\hline \multirow[t]{2}{*}{ No } & 110 & 76.9 & 484 & 85.5 & 594 & 83.8 \\
\hline & \multicolumn{6}{|c|}{$\chi^{2}=6.20, P<0.01$} \\
\hline \multicolumn{7}{|l|}{ Severe } \\
\hline Yes & 33 & 23.1 & 40 & 7.1 & 73 & 10.3 \\
\hline \multirow[t]{2}{*}{ No } & 110 & 76.9 & 526 & 92.3 & 636 & 89.7 \\
\hline & \multicolumn{6}{|c|}{$\chi^{2}=31.68, P<0.001$} \\
\hline
\end{tabular}




\begin{tabular}{|c|c|c|c|c|c|c|c|}
\hline \multirow[t]{2}{*}{ Independent variable } & \multirow[t]{2}{*}{ B } & \multirow[t]{2}{*}{ SE } & \multirow[t]{2}{*}{ df } & \multirow[t]{2}{*}{$P$-value } & \multirow[t]{2}{*}{$\operatorname{Exp}(B)$} & \multicolumn{2}{|c|}{$95 \% \mathrm{Cl}$ for $\exp (\mathrm{B})$} \\
\hline & & & & & & Lower & Upper \\
\hline $\begin{array}{l}\text { Abuse throughout childhood } \\
\text { \& adolescence }\end{array}$ & 1.444 & 0.399 & 1 & $<0.001$ & 4.240 & 1.938 & 9.272 \\
\hline Physical \& sexual abuse & 1.337 & 0.389 & 1 & $<0.001$ & 3.806 & 1.775 & 8.161 \\
\hline Severe abuse & 1.331 & 0.130 & 1 & $<0.001$ & 3.885 & 2.935 & 4.882 \\
\hline
\end{tabular}

$S E=$ standard error; $C l=$ confidence interval; $d f=$ degrees offreedom .

there is a dearth of factual data about domestic violence. However, studies in the USA have reported that 1 out of every 3 women who are murdered is killed by her partner and it is estimated that as many as 4000 women are beaten to death by their husbands or partners each year in the USA $[31,32]$.

Our research findings also provide hypotheses for further cross-cultural research in this area, especially community-based studies and health systems research to compare various communities and women from different social strata. Culture plays a key role in determining societal attitudes towards the female sex and their protection from victimization. On the basis of the 3rd article of the Declaration on the Elimination of Violence against Women issued by the United Nations, member nations are urged to provide equal opportunities for women in terms of "human rights and fundamental freedoms in the political, economic, social, cultural, and civil or any other field" [1]. In terms of equal opportunities, Iranian women compete successfully with men and have achieved high-level positions in the educational, scientific and financial fields. However, cultural changes, especially those affecting traditional beliefs and practices about female upbringing, are challenging for many communities. As a result, a sizeable number of women in the Islamic Republic of Iran still live in male-dominated communities in which the rights of women to have social and physical security from birth to adulthood are ignored.

The findings of this study have theoretical and practical implications for researchers, clinicians and policy-makers concerned with human rights, especially the status of women in society. Sexbased victimization in childhood and adolescence is accompanied by longlasting social and psychological harm, calling for public awareness and community mobilization. Paediatricians, teachers and health experts can play key role in early diagnosis and treatment of the affected victims. Clinically, our findings reinforce the need to document any history of violence during medical consultations with women. This type of data can facilitate clinicians in better understanding the illness behaviour of female patients. Paediatricians can also play a role in identifying any kind of social and psychological deviance among children and adolescents and to screen the families for potential forms of abuse and family dysfunction. To this end the American Academy of Pediatrics has emphasized the role of the paediatrician in family support programmes by early detection and treatment of children who are exposed to stressful family environments [33].

\section{Acknowledgements}

This study was supported by the WHO Regional Office for the Eastern Mediterranean, Cairo, Egypt. We received technical support from the Medical Education Research Centre (MERC) as well as the Behavioural Sciences Research Centre (BSRC) affiliated to Isfahan University of Medical Sciences, Isfahan, Islamic Republic of Iran.

\section{References}

1. Declaration on the Elimination of Violence against Women. Geneva, United Nations, 1993 (A/RES/48/104).

2. Cocker AL et al. Social support protects against the negative effects of partner violence on mental health. Journal of women's health and gender-based medicine, 2002, 11(5):465-76.

3. Statistics crime data brief intimate partner violence: 1993-2001. Washington DC, Bureau of Justice Statistics, United States Department of Justice, 2003.

4. Weingourt R et al. Domestic violence and women's mental health in Japan. International nursing review, 2001, 48(2):102-8.

5. Fikree FF, Bhatti LI. Domestic violence and health of Pakistani women. International journal of gynecology and obstetrics, 1999, 65(2):195-201.
6. Subramaniam P, Srivayogan S. The prevalence and pattern of wife beating in the Trincomalee district in eastern Sri Lanka. Southeast Asian Journal of tropical medicine and public health, 2001, 32(1):186-95.

7. Rao V. Wife-beating in rural South India: A quantitative and economic analysis. Social science \& medicine, 1997, 44:116980.

8. Douki $\mathrm{S}$ et al. Violence against women in Arab and Islamic countries. Achieves of women's mental health, 2003, 6(3):165-7.

9. Zand R. Frequency and correlates of spouse abuse by type: physical, sexual, psychological battering among a sample of Iranian women. International journal of mental health addiction, 2008, 6(3):432-41. 
10. Cano A et al. Marital functioning, chronic pain and psychological distress. Pain, 2004, 107(1-7):99-106.

11. Finkelhor $\mathrm{D}$ et al. Sexual abuse in national survey of adult men and women: prevalence, characteristic, and risk factors. Child abuse and neglect, 1990, 14:19-28.

12. Weiss E, Longhurst JG, Mazure CM. Childhood sexual abuse as a risk factor for depression in women: psychological and neurobiological correlates. American journal of psychiatry, 1999, 156:816-28.

13. Beitchman JH et al. A review of the long-term effects of child sexual abuse. Child abuse and neglect, 1992, 16:101-18.

14. Polusny MA, Follette VM. Long-term correlates of child sexual abuse: theory and review of the empirical literature. Applied and preventive psychology, 1995, 4:143-66.

15. Barkow K et al. Risk factors for depression at 12-months followup in adult primary health care patients with major depression an international prospective study. Journal of affective disorders, 2003, 76(1-3):157-69.

16. McCauley J et al. Clinical characteristics of women with a history of childhood abuse. Journal of the American Medical Association, 1997, 277:1362-68.

17. Beck AT et al. An inventory for measuring depression. Archives of general psychiatry, 1961, 4:561-71.

18. Beck AT, Steer RA, Garbin MG. Psychometric properties of the Beck Depression Inventory: twenty-five years of evaluation. Clinical psychology review, 1988, 8(1):77-100.

19. Diagnostic and statistical manual of mental disorder, 4th ed. Washington DC, American Psychiatric Association, 1994.

20. Straus MA, Gelles RJ, Steinmetz SK. Behind closed doors: a survey offamily violence in America. New York, Doubleday, 1980.

21. McFarlane $J$ et al. Assessing for abuse during pregnancy: severity and frequency of injuries and associated entry into prenatal care. Journal of the American Medical Association, 1992, 267:3176-8.
22. MacMillan HL et al. Prevalence of child physical and sexual abuse in the community. Journal of the American Medical Association, 1997, 256:131-5.

23. Van der Kolk BA, Perry IC, Herman JL. Childhood origins of self-destructive behavior. American journal of psychiatry, 1991, 148:1665-71.

24. Kendall-Tackett KA, Williams LM, Finklehor D. Impact of sexual abuse on children: a review and synthesis of recent empirical studies. Psychological bulletin, 1993, 113:164-80.

25. Osofsky J D. The impact of violence on children. Future child, 1999, 9:33-49.

26. Mullen PE et al. Childhood sexual abuse and mental health in adult life. British journal of psychiatry 1993, 163:721-32.

27. Pillay AL, van der Veen MB, Wassenaar DR. Non-fatal suicidal behavior in women. The role of spousal substance abuse and marital violence. South African medical journal, 2001, 91(5):429-32.

28. Ali A, Toner BB. Self-esteem as a predictor of attitudes toward wife abuse among Muslim women and men in Canada. Journal of social psychology, 2001, 141(1):23-30.

29. Woods SJ. Prevalence and patterns of posttraumatic stress disorder in abused and post abused women. Issues in mental health nursing, 2000, 21(3):309-24.

30. Constantino RE et al. Negative life experiences, depression, and immune function in abused and nonabused women. Biological research for nursing, 2000, 1:190-8.

31. Gilliand MG, Spence PR, Spence RL. Lethal domestic violence in eastern North Carolina. North Carolina medical journal, 2000, 61(5):287-90.

32. Wyszynski ME. Screening women for family violence in the maternal child healthcare setting. Clinical excellence for nurse practitioners, 2000, 4(2):76-82.

33. American Academy of Pediatrics. The pediatrician's role in family support programs. Pediatrics, 2001, 107:195-7. 